\title{
LAPORAN STUDI KELAYAKAN BISNIS "QUEEN TELA-TELA"
}

Diajukan untuk memenuhi dan melengkapi tugas final Mata Kuliah Studi Kelayakan Bisnis dengan Dosen Pengampu Bapak Supriadi, SE., MM

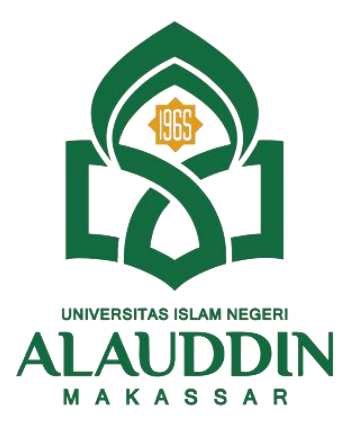

Disusun Oleh:

Kelompok 5

$\begin{array}{llll}\text { Rahmi } & : 90500120121 & \text { Miftahul Jannah } & : 90500120098 \\ \text { Gebhy } & : 90500120089 & \text { Winda Aulya } & : 90500120113 \\ \text { Fitri Aziizah } & : 90500120095 & \text { Tenry Qolbi. S } & : 90500117091 \\ \text { Nur Anisa } & : 90500120088 & \text { Ayu Puspitasari } & : 90500120093\end{array}$

PROGRAM STUDI PERBANKAN SYARIAH

FAKULTAS EKONOMI DAN BISNIS ISLAM

UNIVERSITAS ISLAM NEGERI ALAUDDIN MAKASSAR 


\section{KATA PENGANTAR}

Puji syukur kehadirat Allah SWT yang telah memberikan rahmat dan hidayah-Nya sehingga kami dapat menyelesaikan tugas Laporab Studi Kelayakan Bisnis denagn nama "Queen Tela-Tela" ini dengan tepat waktu. Adapun tujuan dari laporan ini adalah untuk memenuhi tugas pada mata kuliah Studi Kelayakan Bisnis.

Kami mengucapkan terima kasih kepada Bapak Supriadi, S.E.I., M.E.I, selaku dosen yang telah memberikan tugas ini sehingga dapat menambah pengetahuan dan wawasan sesuai bidang yang kami sedang tekuni.

Laporan yang kami tulis ini masih jauh dari kata sempurna. Oleh karena itu, kritik dan saran yang membangun akan kami nantikan demi kesempurnaan makalah ini.

Gowa, 18 November 2021

Penulis 


\section{DAFTAR ISI}

HALAMAN SAMPUL

KATA PENGANTAR ………………………………………………………… ii

DAFTAR ISI..........................................................................................................

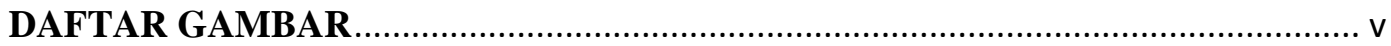

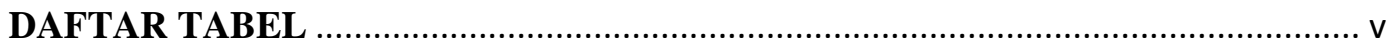

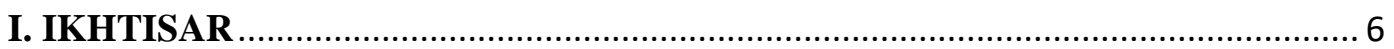

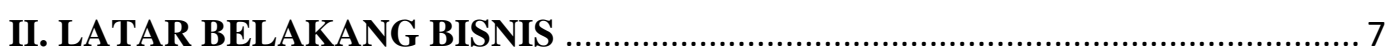

$1.1 \quad$ Alasan Dibangunnya Bisnis.........................................................................

2.2 Kondisi Industri .................................................................................... 8

2.3 Profil Perusahaan ...................................................................................... 9

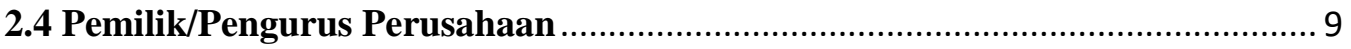

III. ASPEK PASAR DAN PEMASARAN ……………………………………... 10

3.1 Produk yang Dihasilkan ............................................................................... 10

IV. ASPEK TEKNIK DAN TEKNOLOGI ............................................................ 16

4.1 Analisis lokasi bisnis ................................................................................... 16

4.2 Analisis Luas Produksi ................................................................................... 16

4.3 Analisis kesiapan teknologi ………………………………………………... 17

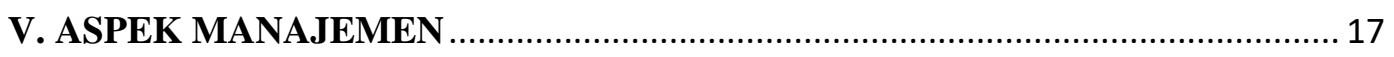

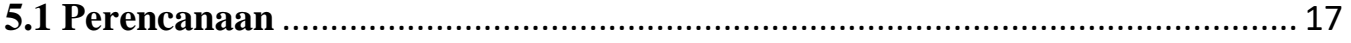

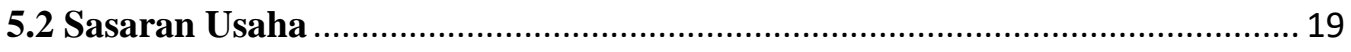

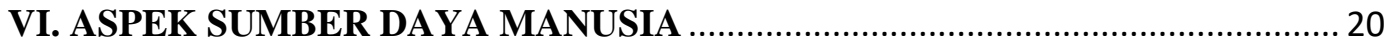

6.1 SDM Pada Bidang Produksi ................................................................... 20

6.2 SDM Pada Bidang Marketing ............................................................... 20

6.3 SDM Pada Bidang Admisitrasi .................................................................. 21

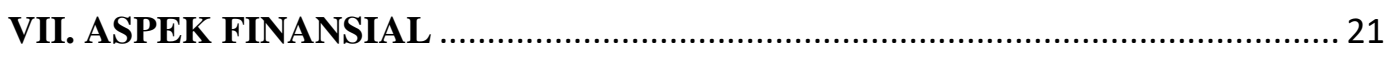

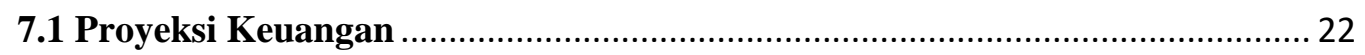

7.2 Sumber Pendanaan ..................................................................................... 22

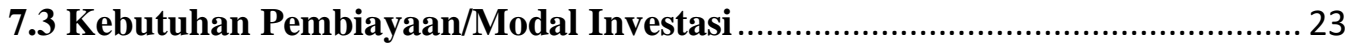

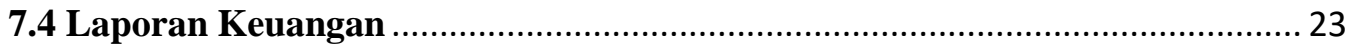


7.5 Perencanaan Data Proyeksi Penjualan bulan 1 (Pertama) ............................. 24

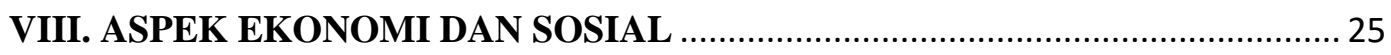

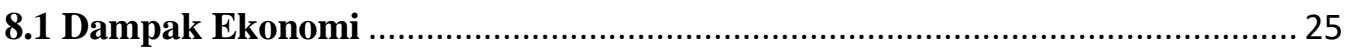

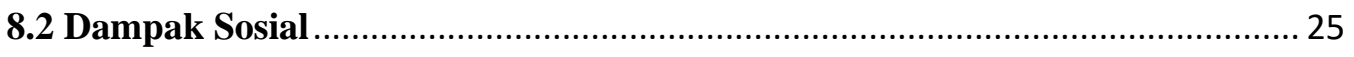

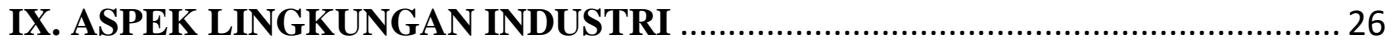

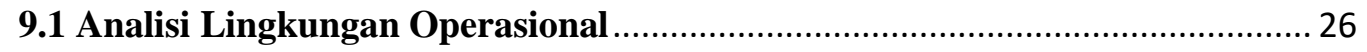

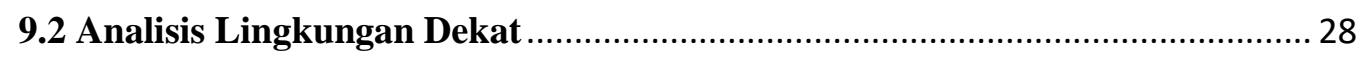

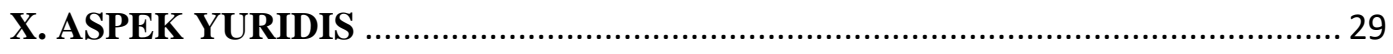

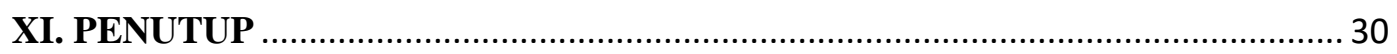

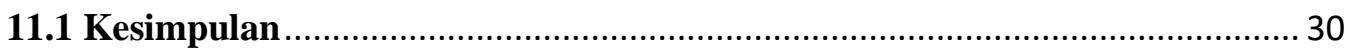

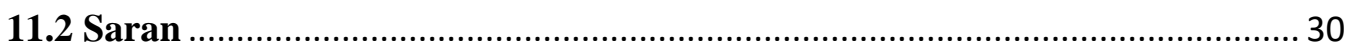

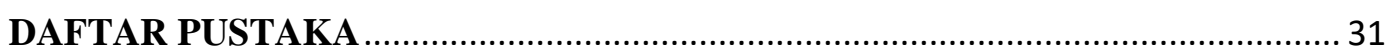




\section{DAFTAR GAMBAR}

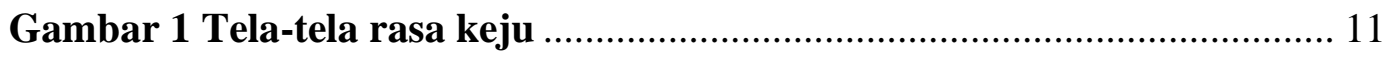

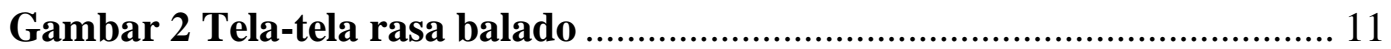

\section{DAFTAR TABEL}

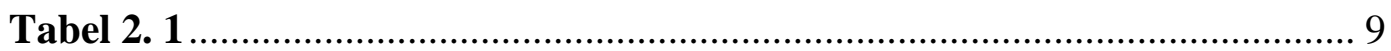

Tabel 2. 2

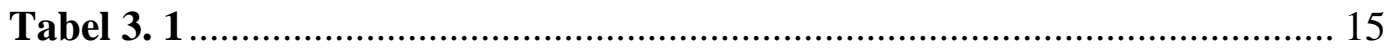

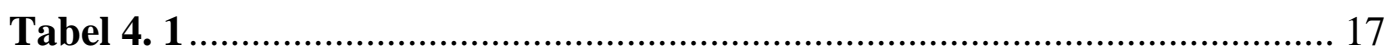

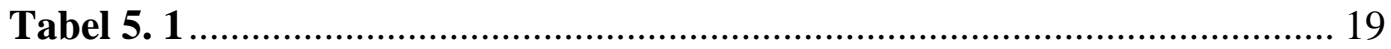

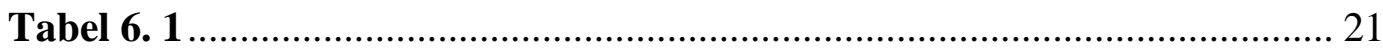

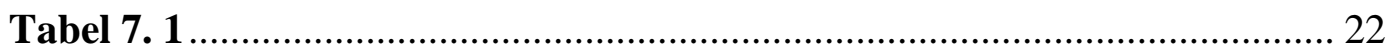

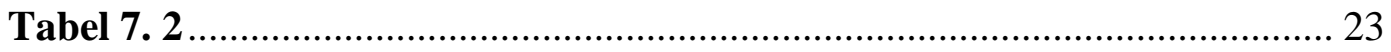

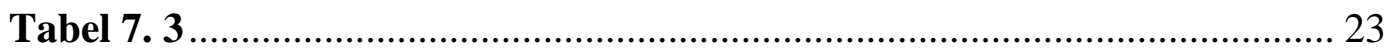

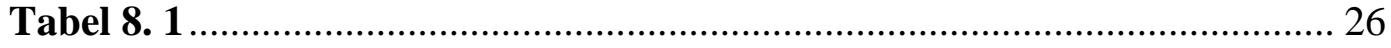

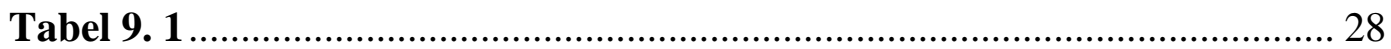

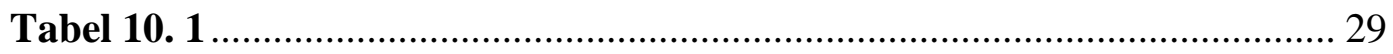




\section{IKHTISAR}

Tela tela merupakan salah satu camilan dari singkong yang menyuguhkan rasa renyah, kering dan sangat lezat. Tela-tela singkong menjadi salah satu camilan yang keberadaaannya telah ada sejak dulu. Camilan singkong ini cukup popular bagi masyarakat Indonesia yang banyak menggemarinya, harganya yang terjangkau membuat tela-tela singkong mudah dinikmati oleh siapapun. Tela-tela singkong disukai mulai dari anak-anak hingga orang dewasa. Bahan singokong dalam pembuatan tela-tela memang menjadi bahan pangan yang mampu menyuguhkan rasa yang lezat. Tela-tela singkong menjadi salah satu varian makanan singkong yang disukai banyak orang. Makanan berbahan singkong ini mudah didapatkan, banyak warung juga penajaja tela-tela singkong yang beterbaran di masyarakat. Mulai dari harga 5 ribu, anda sudah dapat menikmati seporsi tela-tela singkong yang membuat rasanya semakin nikmat.Selain itu kami menyediakan berbagai varian rasa seperti rasa ayam, rasa keju dan rasa balado. 


\section{LATAR BELAKANG BISNIS}

\subsection{Alasan Dibangunnya Bisnis}

Tela-tela singkong kini sangat popular diperbincangkan oleh banyak masyarakat. Tampilannya yang takkalah lezat dengan aneka rasa yang dimiliki menjadikan tela-tela singkong begitu sangat popular. Menikmati tela-tela singkong ini memberikan kepuasan tersendiri dengan kenikmatan yang tiada duanya saat mencicipinya. Kehadiran tela-tela singkong memang mendapat respon yang sangat positif dari berbagai kalangan masyarakat. Bagi pecinta telatela singkong nampaknya hadirnya tela-tela singkong ini memberikan kepuasan tersendiri. Kini tela-tela singkong banyak dicari dan diburu oleh masyarakat yang ingin mencoba untuk mencicipi dan mencoba rasa lezat dari tela-tela singkong. Sekarang ini tela-tela singkong begitu amat popular di tengah masyarakat, hingga pelaku usaha tela-tela singkong kini mulai menjamur di tengah masyarakat.

Tinginya permintaan tela-tela singkong di pasaraan menjadikan peluang dari usaha tela-tela singkong sangat menjanjikan. Kini di masyarakat penjaja telatela singkong mulai banyak bermunculan, pengusaha tela-tela singkong ini pun diutungkan dengan usahanya yang sangat laris manis. Bagi sebagian orang, nampaknya hadirnya tela-tela singkong ini terkesan cukup unik lantaran biasanya tela-tela singkong memiliki bentuk yang kecil namun kini tampil dengan bentuk yang sangat besar. Sehinggah alini sudah banyak dimanfaatkan para pelaku usaha tela-tela singkong untuk memasarkan produk tela-tela singkong buatan mereka, dan menjadi panganan sangat laris dipasaran. Usaha tela-tela singkong merupakan salah satu usaha camilan tradisional dengan keuntungan yang sangat 
menggiurkan. Namanya tela-tela singkong tentu terdengar menarik dan membuat banyak orang semakin lebih penasaran. Sehingga banyak orang yang ingin untuk mencoba mencicipi tela-tela singkong. Namun setelah mencicipi tela-tela singkong, dengan suguhan rasa gurih, lezat dan nikmat membuat banyak orang menjadi semakin ketagihan.

Usaha tela-tela singkong merupakan salah satu usaha yang menguntungkan yang bisa dipilih sebagai usaha yang menjanjikan bagi pelakunya. Banyak orang yang menyukai tela-tela singkong, sehingga kehadiran tela-tela singkong ini kini banyak dicari. Tingginya penggemar tela-tela singkong menjadikan peluang untuk usaha tela-tela singkong kini semakin lebih menjanjikan. Usaha tela-tela singkong dapat dijalankan dalam langkah yang mudah juga untung yang didapatkan terbilang cukup fantastis. Jumlah penggemar tela-tela singkong yang terbilang besar dengan tidak menurun menjadikan usahatela-tela singkong mendatangkan potensi yang besar dalam meraih kesuksesan. Meski usaha tela-tela singkong ini mulai banyak bermunculan di masyarakat namun peminat tela-tela singkong ini tak surut bahkan terus bertambah. Tingginya penggemar tela-tela singkong, membuat usaha tela-tela singkong ini berkembang pesat hingga saat ini.

\subsection{Kondisi Industri}

Sektor usaha "Queen Tela-Tela" dapat dikatakan cukup propektif dengan respon positif oleh berbagai kalangan masyarakat. Usaha tela-tela singkong menjadi suatu pilihan usaha yang menguntungkan hingga banyak orang yang terpincut dalam menjalankan usaha tersebut. Usaha tela-tela singkong menjadi 
suatu usaha camilan yang menyuguhkan rasa nikmat dengan peminatnya tergolong besar, jumlah peminatnya yang melonjak menjadikan usaha tela-tela singkong sebagai salah satu usaha dengan potensi bagus dan juga cemerlang. Usaha tela-tela singkong juga tidak mengenal waktu dan juga musim sehingga usaha ini cocok untuk pilihan usaha yang dijalan kapan pun. Usaha tela-tela singkong juga menjadi salah satu usaha yang bisa dijalankan secara mudah dan juga untung yang didapatkan terbilang sangat fantastis. Peluang untuk usaha telatela singkong ini memang cukup mencengangkan juga sangat cocok menjadi pilihan bisnis yang cemerlang. Tela-tela singkong kini mulai banyak dicari orang sebagai makanan nikmat dan menarik sehingga usaha tela-tela singkong kian laris manis di pasaran.

\subsection{Profil Perusahaan}

Tabel 2. 1

\section{Profil Perusahaan}

\begin{tabular}{|l|l|l|}
\hline 1. & Nama Perusahaan & Queen Tela-Tela \\
\hline 2. & Bidang Usaha & Industri Rumahan \\
\hline 3. & Jenis Produk/Jasa & Makanan ringan \\
\hline 4. & Mulai Berdiri & 01 November 2021 \\
\hline
\end{tabular}

2.4 Pemilik/Pengurus Perusahaan

Tabel 2. 2

Pemilik/Pengurus Perusahaan

\begin{tabular}{|l|l|l|}
\hline No. & \multicolumn{1}{|c|}{ Nama } & \\
\hline 1. & Miftahul Jannah & Pemimpin \\
\hline 2. & Rahmi & Sekretaris \\
\hline 3. & FitriAzizah & Bendahara \\
\hline
\end{tabular}




\begin{tabular}{|l|l|l|}
\hline 4. & Gebhy & Karyawan \\
\hline 5. & WindaAulya & Karyawan \\
\hline 6. & Nur Anisa & Karyawan \\
\hline 7. & Ayu Puspitasari & Karyawan \\
\hline 8 & Tenri Qalby. S & Karyawan \\
\hline
\end{tabular}

\section{ASPEK PASAR DAN PEMASARAN}

\subsection{Produk yang Dihasilkan}

Produk merupakan segala sesuatu yang dapat ditawarkan produsen untuk diperhatikan, diminta, dicari, dibeli, digunakan atau dikonsumsi pasar sebagai pemenuhan kebutuhan atau keinginan pasar yang bersangkutan. Pada bagian ini menjelaskan keseluruhan produk yang dihasilkan. Perencanaan yang perlu dilakukan menyangkut produk (output), terutama pada usaha manufaktur dan industri pengolahan adalah:

\section{Dimensi Produk}

Dimensi produk berkenaan dengan sifat dan ciri-ciri produk yang meliputi bentuk, ukuran, warna serta fungsinya. Produk yang berbahan baku buah ini disajikan dalam bentuk keripik yang disediakan dengan berbagai varian rasa dan harga. Berikut ini adalah berbagai macam produk yang dihasilkan oleh tela-tela antara lain:

- Tela-tela rasa jagung bakar 


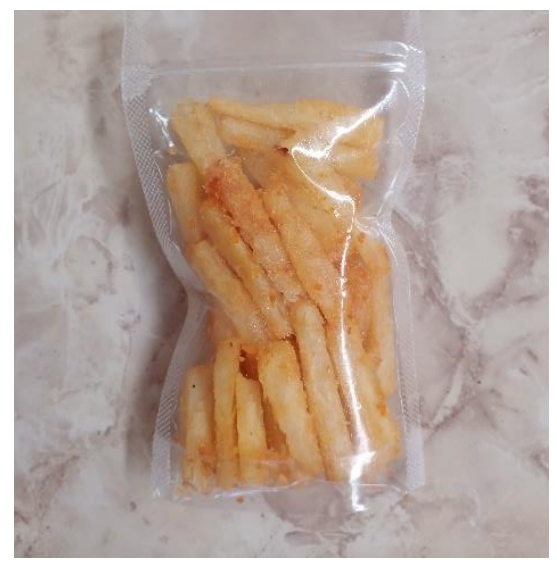

Gambar 1 Tela-tela rasa keju

Tela-tela rasa jagung bakar adalah ubi yang di rebus, dipotong-potong, dan digoreng menjadi crispy lalu dicampur dengan bumbu rasa jagung bakar. Yang menjadi makanan yang bergizi dan enak.

- Tela-tela rasa Balado

Tela-tela rasa balado adalah ubi yang di rebus, dipotong-potong, dan digoreng menjadi krispi lalu di campur dengan bumbu rasa balado. Yang menjadi makanan yang bergizi dan enak.

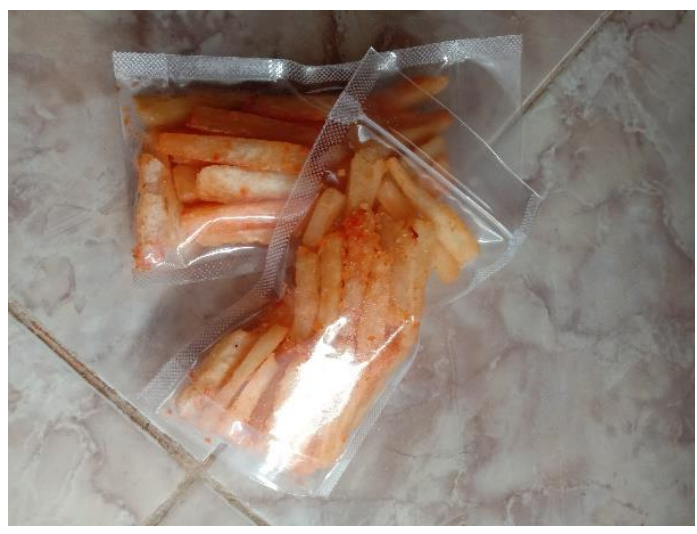

Gambar 2 Tela-tela rasa balado 


\section{Nilai/Manfaat Produk}

Produk tela-tela yang ditawarkan memiliki manfaat yang positif bagi kesehatan konsumen yang merupakan manfaat inti dari produk tela-tela. Ubi yang diolah memiliki banyak kandungan gizi yang bermanfaat. Produk Tela-tela juga memiliki Potential Benefit (manfaat potensial) seperti menjaga lingkungan dan mempedulikan kesehatan pelanggan.

\section{Kegunaan/Fungsi Produk}

Produk konsumsi, yaitu produk yang dibeli dan digunakan oleh konsumen akhir (pemakai akhir). Tela-tela merupakan produk yang dapat dinikmati dengan berbagai pilihan rasa dan harga yang murah. Selain itu kandungan gizi tela-tela yang diproses dengan alat penggoreng sistem hampa tidak jauh berbeda dengan rasa ubi yang enak.

a. Keunggulan Produk

Keunggulan kompetitif produk kami antara lain:

- Rasa yang sangat renyah dan gurih.

- Kemasan yang ramahlingkungan.

- Harga terjangkau dan sesuai dengan kantong konsumen.

- Kebersihan makanan ini terjaga

b. Gambaran Pasar 
Bahan baku yang digunakan dalam proses pembuatan tela-tela ini, dikatakan cukup mudah untuk didapatkan. Sehingga, kami tidak perlu khawatir untuk mendapatkan bahan - bahannya.

c. Target Pasar atau Segmen Pasar yang Dituju

Target adalah menentukan pasar yang akan dituju dalam pemasaran produk. Segmentasi pasar dari penjualan produk ini berdasarkan geografis meliputi penduduk, usia penduduk dan wilayah. Berdasarkan demografis, produk ini tidak dikelompokkan kedalam kriteria tertentu karena produk ini aman di konsumsi oleh siapa saja.

Perusahaan pasti akan memiliki target atau segmentasi pasar yang dituju untuk mengembangkan usaha yang diproduksi oleh perusahaan. Target pasar memberikan prospek yang bagus dimana perusahaan ini dapat memasarkan.

\section{d. Trend Perkembangan Pasar}

Pertumbuhan ekonomi di Indonesia yang semakin berkembang dan membaik saat ini memberikan dampak positif bagi usaha tela-tela ini. Hal ini dikarenakan, perkembangan pertumbuhan ekonomi yang membaik menggambarkan permintaan masyarakat untuk mengkonsumsi jajanan yang sehat dan mengandung gizi yang relatif baik. Hal ini berarti, peluang dalam memproduksi produk tela-tela ini dikategorikan sebagai makanan ringan untuk penambahan unsur nilai gizi bagi kehidupan masyarakat. 
Masyarakat Indonesia sangat mengikuti trend suatu produk di pasar saat ini, termasuk keripik buah. Dengan demikian, perusahaan yakin ketika usaha ini telah berjalan akan menjadi perusahaan yang dapat berkembang cepat. Hal ini dapat dilihat dari kondisi perekonomian Indonesia yang cukup baik dan selera masyarakat untuk mencoba suatu produk yang unik.

Perencanaan kapasitas produksi dilakukan untuk semua mesin, peralatan, dan faktor produksi lainnya sesuai dengan rencana jumlah produk akhir yang akan dihasilkan. Dengan sendirinya, kapasitas produksi sampai dengan tingkatan yang rinci semuanya akan mengacu pada hasil dari perhitungan peluang pasar atas produk yang bersangkutan. Kapasitas produksi biasa dinyatakan dalam unit per periode waktu tertentu (tahun, bulan, minggu, hari, atau jam). Untuk perencanaan strategis, proyeksik apasitas penjualan dilakukan dalam jangka minimal 3 tahun kedepan, sesuai dengan rencana produksinya.

e. Analisis Pesaing

Strategi Pemasaran Perusahaan dilakukan berdasarkan analisa $4 \mathrm{P}$ yang terdiriatas

1) Price (harga)

Strategi mengenai bagaimana produk kita lebih menarik konsumen dari segi harga dibandingkan pesaing. Umumnya konsumen lebih tertarik kepada produk dengan harga yang lebih murah.

2) Product (Produk) 
Strategi mengenai bagaimana produk usaha dapat menarik hati konsumen untuk membelinya. Produk yang ditawarkan merupakan produk tela-tela yang memiliki kualitas terbaik dengan kadar gizi yang tinggi dan menyehatkan.

\section{3) Promotion (Promosi)}

Strategi mengenai bagaimana produk dapat dikenal oleh konsumen melalui cara Personal Selling yaitu promosi melalui penjualan langsung ketempat konsumen berada dengan menawarkan dan mencoba produk langsung.

4) Place (Saluran Distribusi)

Place merupakan cara mendistribusikan produk untuk sampai ketangan konsumen. Yaitu strategi agar membuat produk atau jasa yang ditawarkan lebih mudah terjangkau oleh konsumen, dan dapat tersedia pada sasaran pasar yang tepat.

Perusahaan memiliki lokasi tetap yang mudah dijangkau oleh konsumen. Lokasinya pun cukup strategis karena dekat dengan kampus serta masyarakat disekelilingnya. Sistem distribusi yang dilakukan oleh perusahaan tela-tela adalah secara langsung kekonsumen dan melalui sosial media atau online.

Tabel 3. 1

Kesimpulan Aspek Pasar dan Pemasaran

\begin{tabular}{|c|c|c|c|c|c|c|c|}
\hline \multirow[t]{2}{*}{ No. } & \multirow[t]{2}{*}{ AspekPenilaian } & \multicolumn{5}{|c|}{ Evaluasi } & \multirow[t]{2}{*}{ Ket } \\
\hline & & 1 & 2 & 3 & 4 & 5 & \\
\hline 1. & $\begin{array}{l}\text { Kemampuan mencapai volume } \\
\text { penjualan yang menguntungkan }\end{array}$ & & & & $\checkmark$ & & \\
\hline 2. & $\begin{array}{l}\text { Kemampuan menghasilkan produk } \\
\text { yang lebih baik dibanding pesaing }\end{array}$ & & & & $\checkmark$ & & \\
\hline
\end{tabular}




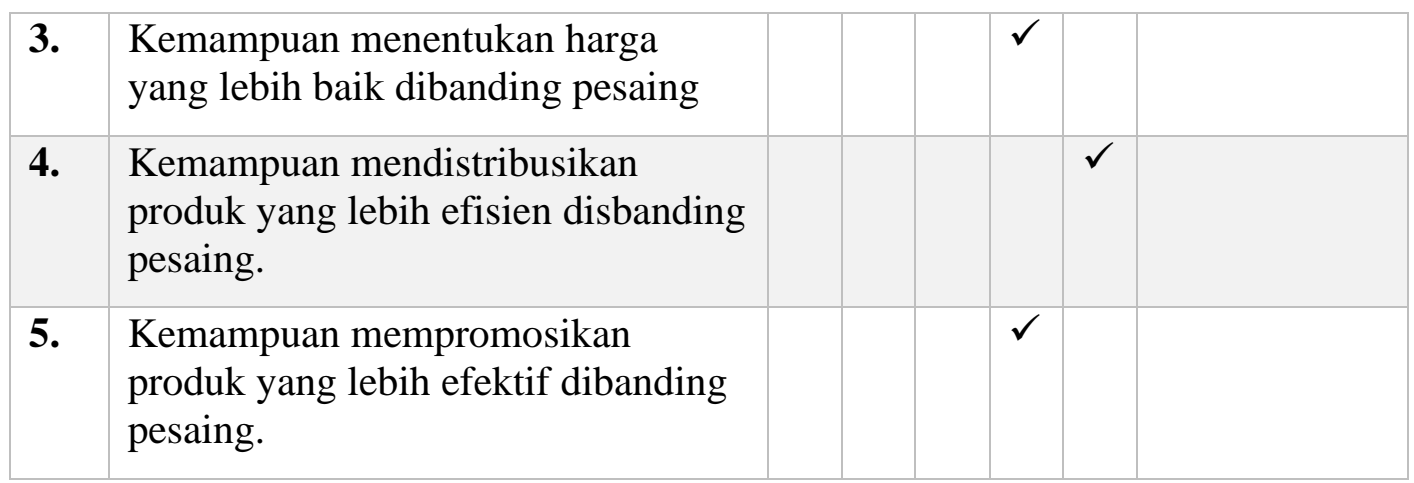

\section{ASPEK TEKNIK DAN TEKNOLOGI}

\subsection{Analisis lokasi bisnis}

Pertimbangan untuk memilih lokasi bisnis yaitu:

1. Ketersediaan bahan baku yang cukup potensional

2. Letak pasar yang dituju dekat

3. Fasilitas transportasi yang baik dan lancar.

Tidak ada lokasi tertentu yang digunakan Queen Tela-Tela karena proses penjualannya dilakukan secara dengan berkeliling di beberapa lokasi keramaian salah satunya di sekitar Kampus II UIN Alauddin Makassar.

\subsection{Analisis Luas Produksi}

Luas produksi dari bisnis ini yaitu mampu menghasilkan output 30-40 bungkus perhari. Hal itu disebabkan karena Queen Tela-Tela merupakan bisnis baru selain itu penjualan hanya dilakukan diwaktu luang saja atau jika tidak ada kegiatan perkuliahan karena mengingat setiap anggota merupakan mahasiswa aktif dan masih memiliki kegiatan lain diluar kampus. 


\subsection{Analisis kesiapan teknologi}

Teknologi yang digunakan dalam kegiatan produksi yaitu teknologi yang masih sederhana seperti peralatan masak pada umumnya. Namun dengan demikian teknologi tersebut mampu untuk menghasilkan output yang banyak. Kemudian untuk mencatat alur penjualan dan pembelian disediakan sebuah komputer yang mendukung dan dalam upaya pemasaran menggunakan kendaraan anggota perusahaan itu sendiri.

Tabel 4. 1

Kesimpulan Analisa Aspek Teknik dan Teknologi

\begin{tabular}{|c|c|c|c|c|c|c|c|}
\hline \multirow[t]{2}{*}{ No. } & \multirow[t]{2}{*}{ Aspek Penilaian } & \multicolumn{5}{|c|}{ Evaluasi } & \multirow[t]{2}{*}{ Ket } \\
\hline & & 1 & 2 & 3 & 4 & 5 & \\
\hline 1. & $\begin{array}{l}\text { Kesiapan teknologi produksi dalam } \\
\text { menghasilkan produk }\end{array}$ & & & & & $\checkmark$ & \\
\hline 2. & $\begin{array}{l}\text { Kesiapan teknologi dalam pendistribusian } \\
\text { pasar }\end{array}$ & & & & $\checkmark$ & & \\
\hline
\end{tabular}

\section{ASPEK MANAJEMEN}

\subsection{Perencanaan}

Aspek Manajemen adalah suatu usaha untuk merencanakan, mengimplementasikan serta mengawasi atau mengendalikan kegiatan pemasaran dalam suatu organisasi agar tercapai semua tujuan organisasi secara efektif dan efisien. Fungsi manajemen pemasaran untuk menganalisis pasar dan lingkungan pemasarannya, sehingga diperoleh keuntungan untuk mendapat peluang usaha. 


\section{Nama Usaha}

Usaha yang kami jalankan bergerak dibidang makanan ringan. Usaha ini kami beri nama "Queen Tela-Tela". Alasan kami memilih nama ini yaitu supaya nama usaha kami menarik dan unik. Kami mengambil kata queen karena yang mengelola usaha ini semuanya perempuan dan tela-tela adalah produk yang akan kami pasarkan nantinya.

\section{Lokasi Usaha}

Pemilihan lokasi usaha ini tidak menentu, karena usaha ini bisa di pasarkan melalui online. Dan biasanya kami juga memasarkannya di tempattempat yang banyak di kunjungi seperti tempat wisata, dll.

\section{Struktur Organisasi}

Struktur organisasi yaitu suatu bagan yang disusun untuk mempermudah dan mengetahui gambar secara sistematis mengenai hubungan kerja sama orangorang yang terdapat dalam suatu badan dalam rangka untuk mencapai suatu tujuan.

Dalam suatu struktur organisasi nantinya kita akan mengetahui sistem manajemen dari organisasi tersebut kemudian dengan struktur organisasi itu akan lebih mudah melakukan koordinasi dan mengetahui tugas masing-masing.

Dari struktur organisasi tersebut dapat dijelaskan bahwa pimpinan memegang kendali perusahaan, kemudian untuk melaksanakan usahanya dibantu oleh tenaga kerja dan bendahara atau administrasi. 
Kewajiban dan tanggung jawab setiap bagian:

a) Pemimpin usaha bertanggung jawab penuh atas segala sesuatu yang terjadi dan berlangsung dalam proses usaha.

- Administrasi bertanggung jawab mengurusi masalah keluar masuknya uang

b) Tenaga kerja

- Mengerjakan semua proses produksi

- Memasarkan barang dagangan

- Mematuhi peraturan dari pimpinan

- Mengerjakan proses pembuatan minuman usaha

\subsection{Sasaran Usaha}

Sasaran utama (pelanggan) dari bisnis ini adalah semua masyarakat. Sebab jika usaha ini dikenali masyarakat dan disenangi maka keuntungan yang didapat banyak.

Tabel 5.1

Kesimpulan Aspek Manajemen

\begin{tabular}{|c|c|c|c|c|c|c|c|}
\hline \multirow[t]{2}{*}{ No. } & \multirow[t]{2}{*}{ Aspek Penilaian } & \multicolumn{5}{|c|}{ Evaluasi } & \multirow[t]{2}{*}{ Ket } \\
\hline & & 1 & 2 & 3 & 4 & 5 & \\
\hline 1. & $\begin{array}{l}\text { Kemampuan menyelesaikan pembangunan } \\
\text { bisnis sesuai dengan waktu yang } \\
\text { direncanakan }\end{array}$ & & & $\checkmark$ & & & \\
\hline 2. & tenaga kerja untuk & & & & & $\checkmark$ & \\
\hline
\end{tabular}


menjalankan bisnis

\section{ASPEK SUMBER DAYA MANUSIA}

Sumber Daya Manusia adalah orang yang berperan penting dalam menjalankan usaha perusahaan untuk mencapai tujuan yang diharapkan. Menurut Sukirno (2004:172), sumber daya manusia adalah orang-orang yang ada dalam sebuah organisasi yang memberikan sumbangan atau ikut berperan baik memberikan sumbangan pemikiran atau melakukan pekerjaan sesuai dengan bidangnya dalam rangka mencapai tujuan organisasi atau perusahaan.

Pada perencanaan awal usaha ini, ada delapan orang yang akan ikut berperan sebagai sumber daya manusia yang masing-masing memiliki tugas sesuai bidangnya masing-masing. Satu orang sebagai pemimpin, sekertaris, bendahara, dan lima orang karyawan. Ada yang berada pada bidang produksi, bidang marketing atau pemasaran, dan pada bidang administrasi.

\subsection{SDM Pada Bidang Produksi}

Pada bidang produksi harus memiliki keuletan dalam bekerja, mengetahui bagaimana proses produksi makanan (tela-tela) tersebut, bagaimana membuat produk yang diproduksi bisa terlihat menarik dan enak untuk dinikmati para konsumen, dan yang paling penting adalah mengetahui bahan utama dari apa yang akan diproduksi.

\subsection{SDM Pada Bidang Marketing}

Pada bidang marketing atau pemasaran, orang yang berperan didalamnya harus mampu menganalisis target dan keinginan pasar, strategi pemasaran yang 
baik, sopan, ramah dan mampu berkomunikasi dengan baik kepada para konsumen.

\subsection{SDM Pada Bidang Admisitrasi}

Pada bidang administrasi, yang ikut berperan didalamnya harus memiliki keahlian dalam pengaplikasian komputer untuk membuat laporan keuangan, bertanggung jawab dan jujur dalam setiap tindakan.

Tabel 6. 1

Kesimpulan Aspek SDM

\begin{tabular}{|c|c|c|c|c|c|c|c|}
\hline \multirow[t]{2}{*}{ No. } & \multirow[t]{2}{*}{ Aspek Penilaian } & \multicolumn{5}{|c|}{ Evaluasi } & \multirow[t]{2}{*}{ Ket } \\
\hline & & 1 & 2 & 3 & 4 & 5 & \\
\hline 1. & $\begin{array}{l}\text { Kesiapan SDM dalam mencapai tujuan } \\
\text { perusahaan }\end{array}$ & & & & $\checkmark$ & & \\
\hline 2. & $\begin{array}{l}\text { Kesiapan SDM dalam menghasilkan } \\
\text { produk }\end{array}$ & & & & $\checkmark$ & & \\
\hline 3. & $\begin{array}{l}\text { Kesiapan SDM menghadapi pesaing } \\
\text { melalui proses marketing atau pemasaran }\end{array}$ & & & & $\checkmark$ & & \\
\hline
\end{tabular}

\section{ASPEK FINANSIAL}

Salah satu komponen yang mendukung pembangunan nasional adalah tersedianya lembaga intermediasi yang mempunyai fungsi menghimpun dana dari masyarakat dan menyalurkan kembali kemasyarakat dalam bentuk kredit dan atau bentuk-bentuk lainnya. 
Berikut ini adalah perencanaan penggunaan oleh queen tela-tela. Datadata ini merupakan gambaran keuangan usaha queen tela-tela di masa yang akan datang.

Laporan ini terdiri atas:

\subsection{Proyeksi Keuangan}

Berikut ini adalah proyeksi laporan keuangan untuk jangka waktu 1 tahun. Aspek finansial dari proposal bisnis dapat memperlihatkan potensi dana yang dimiliki, kebutuhan dana eksternal, perhitungan kelayakan usaha, termasuk di dalamnya 3 performa laporan keuangan: neraca, rugi laba, dan cash flow.

Secara ringkas, dapat diberikan format sederhana perhitungan kelayakan usaha secara finansial sebagai berikut:

\subsection{Sumber Pendanaan}

Tabel 7. 1

Sumber Pendanaan

\begin{tabular}{|c|c|c|c|c|c|c|c|c|c|}
\hline \multirow[t]{2}{*}{ Uraian } & \multicolumn{8}{|c|}{$\begin{array}{c}\text { Presentase } \\
(\%)\end{array}$} & \multirow[t]{2}{*}{ Jumlah } \\
\hline & (a) & (b) & (c) & (d) & (e) & (f) & $(\mathrm{g})$ & (h) & \\
\hline $\begin{array}{l}\text { Modal } \\
\text { Sendiri }\end{array}$ & 20.000 & $\begin{array}{l}20.00 \\
0\end{array}$ & 20.000 & 20.000 & 20.000 & 20.000 & 20.000 & 20.000 & 20.000 \\
\hline Pinjaman & 0 & 0 & 0 & 0 & 0 & 0 & 0 & 0 & 0 \\
\hline $\begin{array}{l}\text { Jumlah } \\
(1+2)\end{array}$ & & & & & & & & & 160.000 \\
\hline
\end{tabular}




\subsection{Kebutuhan Pembiayaan/Modal Investasi}

Tabel 7.2

Kebutuhan Pembiayaan

\begin{tabular}{|l|l|}
\hline \multicolumn{1}{|c|}{ Uraian } & \multicolumn{1}{c|}{ Jumlah } \\
\hline Peralatan & 30.000 \\
\hline Bahan Baku & 52.000 \\
\hline Jumlah & 82.000 \\
\hline
\end{tabular}

\subsection{Laporan Keuangan}

Tabel 7.3

Modal Investasi bulan pertama

\begin{tabular}{|l|l|l|}
\hline \multicolumn{1}{|c|}{ Uraian } & \multicolumn{1}{|c|}{ Jumlah } & \multicolumn{1}{c|}{ Total } \\
\hline a. Investasi & 160.000 & 160.000 \\
\hline b. Penggunaan dana & 82.000 & 82.000 \\
\hline c. Arus kas bersih (a-b) & $160-82.000$ & 78.000 \\
\hline d. Penjualan & 50 pcs x 5.000 & 250.000 \\
\hline e. Pendapatan (c+d) & $78.000+250.000$ & 328.000 \\
\hline f. Beban-beban & 100.000 & 100.000 \\
\hline g. Kenaikan Investasi (e-f) & $328.000-100.000$ & 228.000 \\
\hline h. Keadaan kas awal & 0 & 0 \\
\hline i. Keadaan kas akhir (g+h) & 228.000 & 228.000 \\
\hline
\end{tabular}




\subsection{Perencanaan Data Proyeksi Penjualan bulan 1 (Pertama)}

Investasi

$$
\text { Rp } 160.000
$$

Penggunaan Dana

- Bahan Baku Rp 52.000 x 1 bulan= Rp. 52.000

- Kebutuhan Investasi

Rp. $82.000+$

Total Penggunaan dana:

Rp. 134.000

Arus Kas Bersih :

(Investasi - Penggunaan dana)

Rp. 160.000

Rp. $134.000-$

Rp. 26.000

Penjualan 50 pcs $x$ Rp.5.000 = Rp. 250.000

Total Beban

- Biaya Listrik \& Air

Rp. 25.000

- Biaya Telp

Rp. 20.000

- Biaya Transportasi

Rp. $55.000+$

Rp. 100.000

Kenaikan Investasi

Rp. 328.000

Pendapatan

$\underline{\text { Rp. } 100.000-}$

Rp. 228.000

Keadaan Kas Awal

Rp. 0

Keadaan Kas Akhir 


\section{ASPEK EKONOMI DAN SOSIAL}

\subsection{Dampak Ekonomi}

Pendirian usaha Queen Tela-Tela akan membawa dampak secara khusus terhadap struktur ekonomi masyarakat di lingkungan pendirian usaha Queen TelaTela, hal tersebut dapat dilihat dari peningkatan penghasilan karyawan. Di mana pendapatan rata-rata pekerja akan meningkat dengan gaji yang diterimanya ditambah dengan bonus-bonus yang diberikan apabila jumlah konsumen yang membeli tela-tela lebih banyak dari jumlahnya dari waktu ke waktu yang biasanya.

\subsection{Dampak Sosial}

Pendirian usaha Queen Tela-Tela ini, akan memberikan produk dan jasa kepada seluruh kalangan masyarakat baik dari anak-anak sampai orang dewasa. Dengan adanya rencana pendirian usaha Queen Tela-Tela ini, akan membuka peluang untuk menyerap tenaga kerja langsung di sekitar lokasi pendirian. Selainitu juga meningkatkan kreativitas anak muda baik di sekitar lingkungan usaha maupun di luar. Hal tersebut juga dapat membantu program pemerintah dalam menanggulangi masalah keterbatasan lapangan kerja serta meningkatkan pendapatan dan kesejahteraan masyarakat. 
Tabel 8. 1

Kesimpulan Aspek Sosial dan Ekonomi

\begin{tabular}{|c|c|c|c|c|c|c|c|}
\hline \multirow[t]{2}{*}{ No. } & \multirow[t]{2}{*}{ Aspek Penilaian } & \multicolumn{5}{|c|}{ Evaluasi } & \multirow[t]{2}{*}{ Ket } \\
\hline & & 1 & 2 & 3 & 4 & 5 & \\
\hline 1. & $\begin{array}{l}\text { Dampak perusahaan pada tingkat } \\
\text { pendapatan karyawan }\end{array}$ & & & & & $\checkmark$ & \\
\hline 2. & $\begin{array}{l}\text { Kemampuan perusahaan membuka } \\
\text { lapangan pekerjaan }\end{array}$ & & & $\checkmark$ & & & \\
\hline
\end{tabular}

\section{ASPEK LINGKUNGAN INDUSTRI}

\subsection{Analisi Lingkungan Operasional}

Lingkungan operasional merupakan lingkungan yang paling dekat dengan aktivitas perusahaan. Lingkungan operasional perusahaan meliputi pesaing, kreditor, pemasok dan pegawai.

\section{Lingkungan Pesaing}

Pesaing adalah entitas yang menjual produknya sama, baik berupa barang atau jasa. Pesaing berpengaruh besar terhadap keberhasilan bisnis yang akan dijalankan. Perusahaan harus memiliki keunggulan dalam persaing di industri yang sama untuk dapat memenangka npersaingan. Dalam usaha bisnis tela-tela singkong ini tentu terdapat pesaing yang banyak. Kelebihan dari pesaing Queen Tela-Tela adalah mereka mudah dikenali oleh masyarakat luas karena banyaknya anggota perusahaan dari berbagai tempat di Makassar/Gowa dan sekitarnya sehingga proses promosi mudah untuk dilakukan. Kekurangan dari pesaing adalah 
kurangnya ciri khas yang digunakan pada Queen Tela-Tela karena usaha ini sudah banyak tersebar di masyarakat.

\section{Lingkungan Pelanggan}

Pelanggan bisa dijadikan tolak ukur apakah konsumen menyukai produk yang dihasilkan, agar konsumen membeli terus-menerus produk yang dihasilkan. Pelanggan adalah faktor terpenting yang akan memajukan usaha bisnis. Sasaran pelanggang Queen Tela-Tela adalah mahasiswa, belajar, dan masyarakat sekitar.

\section{Lingkungan Pemasok}

Pemasok adalah perusahaan yang mendistribusikan bahan baku kepada perusahaan lain. Pemasok yang digunakan Queen Tela-Tela adalah salah satu anggota perusahaan. Pemasok ini digunakan untuk memudahkan perusahaan memproduksi produknya selain itu juga mampu mengurangi biaya produksi perusahaan.

\section{Lingkungan Kreditur}

Dalam usaha ini, pemilik perusahaan tidak mengambil pinjaman dari pihak manapun karena modal yang digunakan dalam usaha ini terbilang kecil dan itu diperoleh dari patungan anggota perusahaan.

\section{Lingkungan Pegawai}

Pegawai usaha ini terdiri dari 7 orang yang merupakan anggota dari Queen Tela-Tela itu sendiri. 


\subsection{Analisis Lingkungan Dekat}

\section{Ancaman Masuk Pendatang Baru}

Pendatang baru dalam pasar persaingan sempurna akan mudah untuk masuk ke pasar sehingga persaingan dalam menjual produk lebih ketat. Kondisi persaingan yang ketat mengharuskan penyusunan dan memunculkan inovasi. Dengan adanya Queen Tela-Tela bisa saja pendatang baru menjual produk dengan bahan baku yang sejenis namun dengan inovasi yang berbeda.

\section{Ancaman Produk Pengganti}

Tidak ada rencana untuk mengubah produk pengganti tetapi akan lebih berinovasi dan menonjolkan produk yang akan dijual.

\section{Persaingan Sesama Perusahaan Dalam Industri}

Dilingkungan masyarakat saat ini, dapat dilihat bahwa persaingan usaha tela-tela singkong sangat ketat. Namun Queen Tela-Tela menghadapi persaingan tersebut dengan memberikan berbagai inovasi baru.

Tabel 9. 1

\section{Kesimpulan Aspek Industri}

\begin{tabular}{|l|l|l|l|l|l|l|l|}
\hline No. & AspekPenilaian & \multicolumn{3}{|l|}{ Evaluasi } & \multicolumn{3}{|l|}{ Ket } \\
\hline 1. & Kondisi lingkungan pemasok & 1 & 2 & 3 & 4 & 5 & \\
\hline 2. & Kondisi lingkungan pelanggan & & & & & $\checkmark$ & \\
\hline 3. & Kondisi lingkungan kreditur & & & & $\checkmark$ & & \\
\hline
\end{tabular}




\begin{tabular}{|l|l|l|l|l|l|}
\hline 4. & Kondisi lingkungan pegawai & & $\checkmark$ & \\
\hline 5. & Kondisi hambatan masuk & & & $\checkmark$ & \\
\hline 6. & Kondisi ancaman produk pengganti & & & & $\checkmark$ \\
\hline 7. & Kondisi persaingan sesama & & & $\checkmark$ & \\
\hline & perusahaan dalam industry & & & & \\
\hline
\end{tabular}

\section{ASPEK YURIDIS}

Queen Tela-Tela yang dijalankan merupakan bisnis yang tidak berbadan hukum, karena perusahaan perseorangan atau perusahaan dagang. Selain itu harta kekayaan perusahaan dan pribadi tidak terpisah dengan jelas, atau pada prinsipnya usaha ini tidak mempunyai kekayaan sendiri.

Dari segi produk yang dihasilkan dan pendirian bisnis ini tentunya tidak melanggar hukum yang berlaku, karena dalam pembuatannya tidak menggunakan bahan yang berbahaya dan juga tidak terdapat unsur bahan-bahan yang haram. Dari segi pendirian usaha sangat mudah hanya menentukan nama perusahaan, produk yang akan diproduksi, menentukan tempat perusahaan, serta menentukan maksud dan tujuan yang spesifik dari perusahaan ini.

Tabel 10. 1

Kesimpulan Aspek Yuridis

\begin{tabular}{|c|c|c|c|c|c|c|c|}
\hline \multirow[t]{2}{*}{ No. } & \multirow[t]{2}{*}{ Aspek Penilaian } & \multicolumn{5}{|c|}{ Evaluasi } & \multirow[t]{2}{*}{ Ket } \\
\hline & & 1 & 2 & 3 & 4 & 5 & \\
\hline 1. & $\begin{array}{l}\text { Kemampuan perusahaan menaati } \\
\text { hukum }\end{array}$ & & & & & $\checkmark$ & \\
\hline
\end{tabular}




\section{PENUTUP}

\subsection{Kesimpulan}

Tela-tela merupakan makanan yang bahan dasarnya dari singkong, sehingga banyak diminati oleh masyarakat. Tinginya permintaan tela-tela singkong di pasaraan menjadikan peluang dari usaha tela-tela singkong sangat menjanjikan, baik itu kalangan anak-anak, dewasa hingga orang tua. Sehingga kami memilih usaha tela-tela singkong sebagai usaha kami. Dalam penyusunan laporan studi kelayakan bisnis ini menggunakan delapan aspek yaitu :

- Aspek pasar dan pemasaran

- Aspek Teknik dan Teknologi

- Aspek Manajemen

- Aspek Sumber Daya Manusia

- Aspek Finansial

- Aspek Ekonomi dan Sosial

- Aspek Lingkungan Industri

- Aspek Yuridis

\subsection{Saran}

Berikut beberapa saran yang dapat kami berikan dilihat dari perkembangan dan kemajuan usaha Tela-tela yaitu sebagai berikut :

a. Harus lebih meningkatkan kualitas dan kuantitas produk untuk mendorong perkembangan usaha. 
b. Mengembangkan kreativitas dengan melibatkan diri dan karyawan dalam menjalankan usaha, agar menjadi motivasi bagi para karyawan untuk pengembangan usaha.

c. Dengan harga yang murah, akan mendorong pembeli untuk membeli produk yang kita jual. Karena harga merupakan salah satu tolak ukur bagi calon pembeli.

d. Membuat daya tarik tersendiri produk yang kita buat untuk membuat konsumen menikmati produk yang kita jual.

\section{DAFTAR PUSTAKA}

Agus. Studi Kelayakan Bisnis : Analisis Intregratif dan Studi Kasus. Malang: UIN-Maliki Press, 2011.

Friyan Dwi Kristanto, dkk. "ANALISIS KELAYAKAN BISNIS DITINJAU DARI ASPEK KEUANGAN PRODUK EKONOMI KREATIF (Studi Kasus Pada Distro "Powernoise Merch")." Junal Ilmiah Riset Manajemen 8.09 (2019): 25-26.

Hidayanti, Arif. Studi Kelayakan Bisnis. Sumatra Barat: Insan Cendekia Mandiri, 2021.

Irna Novia Fitriani, dkk. "Studi Kelayakan Bisnis Bakso Lotus Jembar." The Journak Gastronomy Tourism 5.1 (2018): 1-11.

Kasmir, Jakfar. Studi Kelayakan Bisnis : Edisi Revisi. Jakarta: Prenada Media, 2015. 
M munir, dkk. "STUDY KELAYAKAN BISNIS DALAM ASPEK LINGKUNGAN HIDUP." JURNAL LABATILA 3.1 (2018): 46-60.

Nur Muflihah, dkk. "Studi Kelayakan Home Industry Bonsay (Abon Sayur) Analisis Aspek Pasar Dan Pemasaran." Jurnal Ilmu-Ilmu Teknik-Sistem 15.2 (2019): 1-7.

Sulasih Sulasih, dkk. Studi Kelayakan Bisnis . Medan: Yayasan Kita Menulis, 2021. 